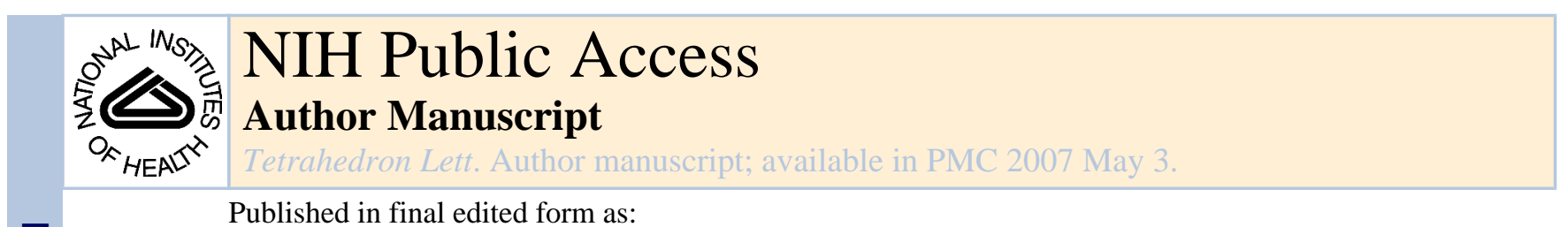

Published in final edited form as:

Tetrahedron Lett. 2007 January 22; 48(4): 563-565.

\title{
Fluorous synthesis of sclerotigenin-type benzodiazepine- quinazolinones
}

\author{
Wei Zhang ${ }^{\mathrm{a},{ }^{*}, \text { John P. Williams }}{ }^{\mathrm{b}}$, Yimin Lu ${ }^{\mathrm{a}}$, Tadamichi Nagashima ${ }^{\mathrm{a}}$, and Qainli Chu ${ }^{\mathrm{a}}$ \\ a Fluorous Technologies, Inc., University of Pittsburgh Applied Research Center, 970 William Pitt Way, \\ Pittsburgh, PA 15238, USA
}

b Neurocrine Biosciences, 12790 El Camino Real, San Diego CA92130, USA

\begin{abstract}
A new synthetic protocol for sclerotigenin-type benzodiazepine-quinazolinone library scaffold is introduced. A fluorous benzyl protecting group is used for synthesis of 4-benzodiazepine-2,5-dione intermediate and also as a phase tag for fluorous solid-phase extraction (F-SPE).
\end{abstract}

\section{Keywords}

sclerotigenin; benzodiazepine-quinazolinone; 1,4-benzodiazepine-2,5-dione; fluorous synthesis; solid-phase extraction

Sclerotigenin was isolated from the sclerotia of Penicillium sclerotigenum and has shown promising antiinsectan activity. ${ }^{1}$ It is the simplest member of the benzodiazepinequinazolinone natural alkaloid family. Other members in this family such as circumdatins A$\mathrm{G}$ isolated from terrestrial fungus Aspergillus ochraceus ${ }^{2}$ and benzomalvins A-C isolated from fungus Penicillium sp also possess interesting biological activities. ${ }^{3}$<smiles>O=C1NCc2nc3ccccc3c(=O)n2-c2ccccc21</smiles>

sclerotigenin<smiles>[Y16]C1NC(=O)c2cc(O)ccc2-n2c1nc1ccccc1c2=O</smiles>

circumdatin C

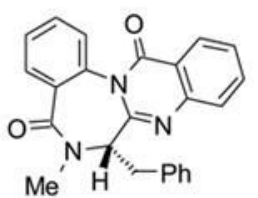

benzomalvin $\mathrm{A}$<smiles>CC(C)(C)[C@H]1NC2([C@H]3NC(=O)c4ccccc4N3c3nc4ccccc4c(=O)n32)[C@H](O)c2ccccc21</smiles>

$(-)$ asperlicin

Privileged 1,4-benzodiazepine-2,5-dione ring systems are the key intermediates for synthesis of benzodiazepine-quinazolinone alkaloids. ${ }^{4}$ As part of our continuous effort on the development of fluorous synthetic protocols, we have employed a series of fluorous protecting groups for library synthesis. ${ }^{5,6}$ Reported here is a new approach to synthesize benzodiazepinedione scaffold using fluorous benzyl as a protecting group and also as a phase tag for fluorous solid-phase extraction (F-SPE). ${ }^{7}$ Further derivatization of benzodiazepinediones leads to formation of sclerotigenin ring skeleton.

\footnotetext{
*Corresponding author. Tel.: +412-826-3062; fax: +412-826-3053; e-mail: w.zhang @ fluorous.com.

Publisher's Disclaimer: This is a PDF file of an unedited manuscript that has been accepted for publication. As a service to our customers we are providing this early version of the manuscript. The manuscript will undergo copyediting, typesetting, and review of the resulting proof before it is published in its final citable form. Please note that during the production process errors may be discovered which could affect the content, and all legal disclaimers that apply to the journal pertain.
} 
Taking the advantage that numbers of conventional solution-phase and solid-phase synthetic methods for benzodiazepine have been reported in literature, ${ }^{8}$ we adopted Ellman's solid-phase method for fluorous synthesis (Scheme 1). ${ }^{9}$ Fluorous benzaldehyde 1 prepared by reaction of a hydroxybenzaldehyde with a fluorous alcohol was used as the starting material. Compound $\mathbf{2}$ was produced by reductive amination of $\mathbf{1}$ with an amino ester. Compound $\mathbf{2}$ was reacted with an anthranilic acid in the presence of 1-ethyl-3-3-dimethylaminopropyl)carbodiimide (EDCI) and $N$-methylpyrrolidine (NMP). The 1,4-benzodiazepine-2,5-dione ring formation was accomplished by base-promoted cyclization of $\mathbf{3}$. Compounds $\mathbf{2 , 3}$, and $\mathbf{4}$ generated in this reaction sequence were purified by simple workup or F-SPE with FluoroFlash ${ }^{\circledR}$ cartridges.

${ }^{10} \mathrm{In} \mathrm{F-SPE}$, the first wash with 80:20 $\mathrm{MeOH}-\mathrm{H}_{2} \mathrm{O}$ eluted the non-fluorous components. The desired fluorous compound was eluted with $100 \% \mathrm{MeOH}$. A total of nine analogs of compound 4 with substitution variations (R1 and $\mathrm{R}^{2}$ ) were prepared. ${ }^{11}$

With nine different benzodiazepinediones $\mathbf{4}$ in hand, we then conducted parallel synthesis to construct the quinazolinone ring skeleton (Scheme 2). ${ }^{1 \mathrm{c}}$ Compound $\mathbf{4}$ was acylated with 2nitrobenzoyl chloride in the presence of $t$ - $\mathrm{BuN}=\mathrm{P}\left(\mathrm{NMe}_{2}\right)_{3}$ as a base to give compound $\mathbf{5}$ (Table 1). If substituted 2-nitrobenzoyl chloride was employed for acylation, the third diversity point (R3) could be introduced. Compounds 5 were purified by automated RapidTrace F-SPE. ${ }^{12}$ The nitro group of $\mathbf{5}$ was reduced with zinc dust in acetic acid under sonication conditions. Resulted amino group simultaneously underwent cyclization to form quinazolinone ring of $\mathbf{6}$. The parallel sonication reactions of 5 gave the reduction/cyclization products 6 in a broad range of yield (21-73\%). Since some reactions had low yields, F-SPE was not sufficient for purification. Reverse-phase chromatography was applied to purify compounds 6 . The capability to purify fluorous compounds by non-fluorous technique is a useful option. It could be a difficult task in solid-phase synthesis to separate resin-bound impurities. At the last step, F-benzyl tag of compounds 6 was removed by treated with 90:5:5 TFA- $\mathrm{H}_{2} \mathrm{O}$-dimethylsulfide (DMS) under microwave radiation, followed by F-SPE on RapidTrace ${ }^{\circledR}$ workstation to give the final product 7 with the sclerotigenin ring skeleton. ${ }^{13}$

In summary, we have developed a new approach for the synthesis of fluorous 1,4benzodiazepine-2,5-diones. The key intermediates can be readily converted to sclerotigenin ring skeleton. The new method which produces the library scaffold with substitution variation coupled with the simple F-SPE separation is an alternative way for solution-phase parallel synthesis of benzodiazepine-quinazolinone analogs.

\section{Acknowledgements}

This work was supported by the National Institutes of General Medical Sciences SBIR grant (2R44GM067326-02A1).

\section{References}

1. a) Penhoat M, Bohn P, Dupas G, Papamicael C, Marsais F, Levacher V. Tetrahedron Asymm 2006;17:281-286. b) Liu JF, Kaselj M, Isome Y, Chapnick J, Zhang B, Bi G, Yohannes D, Yu L, Baldino CM. J Org Chem 2005;70:10488-10493. [PubMed: 16323862] c) Grieder A, Thomas AW. Synthesis 2003:1707-1711. d) Snider BB, Busuyek MV. Tetrahedron 2001;57:3301-3307. e) He F, Foxman BM, Snider BB. J Am Chem Soc 1998;120:6417-6418.

2. Rahbaek L, Breinholt J. J Nat Prod 1999;62:904-905. [PubMed: 10395516]

3. a) Sun HH, Barrow CJ, Sedlock DM, Gillum AM, Cooper R. J Antibiotics 1994;47:515-522. [PubMed: 7518818] b) Sugimori T, Okawa T, Eguchi S, Kakehi A, Yashima E, Okamoto Y. Tetrahedron 1998;54:7997-8008.

4. Horton DA, Bourne GT, Smythe ML. Chem Rev 2003;103:893-930. [PubMed: 12630855]

5. a) Zhang W, Lu Y, Chen CH-T, Zeng L, Kassel DB. J Comb Chem 2006 8:687-695. b) Zhang W, Lu Y, Chen CH-T, Curran DP, Geib S. Eur J Org Chem 2006:2055-2059. c) Zhang W, Lu Y, Geib S. Org Lett 2005;7:2269-2272. [PubMed: 15901186] d) Zhang W, Chen CHT. Tetrahedron Lett 
2005;46:1807-1810. [PubMed: 18079977] e) Lu Y, Zhang W. Mol Diversity 2005;9:91-98. f) Nagashima T, Zhang W. J Comb Chem 2004;6:942-949. [PubMed: 15530122] g) Lu Y, Zhang W. QSAR Comb Sci 2004;23:827-835. h) Zhang W, Tempest P. Tetrahedron Lett 2004;45:6757-6760. i) Zhang W, Lu Y. Org Lett 2003;5:2555-2558. [PubMed: 12841779] j) Chen CHT, Zhang W. Org Lett 2003;5:1015-1017. [PubMed: 12659562] k) Zhang W. Org Lett 2003;5:1011-1014. [PubMed: 12659561] 1) Zhang W, Luo Z, Chen CH-T, Curran DP. J Am Chem Soc 2002;124:10443-10450. [PubMed: 12197746]

6. Selected reviews on fluorous synthesis. a) Curran DP. Aldrichemica Acta 2006;39:3-9.b) CurranDPGladyszJACurranDPHorvathITHandbook of Fluorous ChemistryWileyVCHWeinheim2004101127 c) Zhang W. Chem Rev 2004;104:2531-2556. [PubMed: 15137799] d) Zhang W. Curr Opin Drug Discov Develop 2004;7:784-797. e) Zhang W. Tetrahedron 2003;59:44754489. f) Curran DP. Angew Chem Int Ed Eng 1998;37:1174-1196.

7. For reviews on F-SPE, see a) Zhang W, Curran DP. Tetrahedron 2006;62:11837-11865.b) CurranDPGladyszJACurranDPHorvathITHandbook of Fluorous ChemistryWileyVCHWeinheim2004101127 c) Curran DP. Synlett 2001:1488-496.. See also d) Zhang W, Lu Y, Nagashima T. J Comb Chem 2005;7:893-897. [PubMed: 16283798]

8. For a recent review on solid-phase synthesis of benzodiazepines, see Kamal A, Reddy KL, Devaiah V, Shankaraiah N, Reddy DR. Mini-Rev Med Chem 2006;6:53-68. [PubMed: 16457632]

9. Boojamra CG, Burow KM, Thompson LA, Ellman JA. J Org Chem 1997;62:1240-1256.

10. FluoroFlash ${ }^{\circledR}$ SPE cartridges are available from Fluorous Technologies, Inc. (www.fluorous.com)

11. A general procedure for the synthesis of compounds 2 and $\mathbf{4}$. To a solution of leucine methyl ester hydrochloride (7.6 g, $42 \mathrm{mmol}$ ), 2,6-dimethoxy-4-[3-(perfluorooctyl)propyloxy]benzaldehyde 1 (26 $\mathrm{g}, 40 \mathrm{mmol})$, and $\mathrm{N}, \mathrm{N}$-diisopropylethylamine $(7 \mathrm{~mL}, 0.04 \mathrm{~mol})$ in $\mathrm{CH}_{2} \mathrm{Cl}_{2}(0.3 \mathrm{~L})$ was added $4 \AA$ molecular sieves $(3 \mathrm{~g})$ at $23{ }^{\circ} \mathrm{C}$. $\mathrm{NaBH}(\mathrm{OAc})_{3}(13 \mathrm{~g}, 60 \mathrm{mmol})$ was added after $4 \mathrm{~h}$, then water was added after additional $3 \mathrm{~h}$. The $\mathrm{CH}_{2} \mathrm{Cl}_{2}$ layer was washed with aq. $\mathrm{NH}_{4} \mathrm{Cl}$ and brine. After most of the solvent was removed using a rotary evaporator, the residue was passed through a pad of silica gel $(50 \mathrm{~mL})$. The product was eluted with hexanes-EtOAc $(1: 1,300 \mathrm{~mL})$. The concentrated product was further triturated with hexanes- $\mathrm{Et}_{2} \mathrm{O}$ to give the desired compound $\mathbf{2}\left(\mathrm{R}^{1}=i\right.$ - $\mathrm{Bu}, 3.9 \mathrm{~g}, 95 \%$ yield). ${ }^{1} \mathrm{H}$ NMR $\left(270 \mathrm{MHz}, \mathrm{CDCl}_{3}\right) \delta 6.08(\mathrm{~s}, 2 \mathrm{H}), 4.02(\mathrm{t}, 2 \mathrm{H}, J=5.8 \mathrm{~Hz}), 3.78(\mathrm{~s}, 6 \mathrm{H}), 3.59(\mathrm{~s}$, $3 \mathrm{H}), 3.26(\mathrm{t}, 1 \mathrm{H}, J=7.1 \mathrm{~Hz}), 2.45-2.00(\mathrm{~m}, 5 \mathrm{H}), 1.82-1.35(\mathrm{~m}, 3 \mathrm{H}), 0.88(\mathrm{~d}, 3 \mathrm{H}, J=6.5 \mathrm{~Hz}), 0.81$ $(\mathrm{d}, 3 \mathrm{H}, J=6.4 \mathrm{~Hz}) .{ }^{13} \mathrm{C} \mathrm{NMR}\left(67.5 \mathrm{MHz}, \mathrm{CDCl}_{3}\right) \delta 176.4,159.3,108.9,90.7,66.3,59.0,55.5,51.3$, $42.8,39.9,28.2,27.9,27.5,24.8,22.6,22.0,20.5$. LC-MS (APCI+) $m / z, 772[\mathrm{M}+1]^{+}$. To a solution of $2\left(\mathrm{R}^{1}=i\right.$-Bu, $\left.4.3 \mathrm{~g}, 5.6 \mathrm{mmol}\right)$ in $N$-methylpyrrolidine $(30 \mathrm{~mL})$, 4-chloroanthranilic acid $(1.9 \mathrm{~g}$, $11 \mathrm{mmol})$ and $\mathrm{EDCI}-\mathrm{HCl}(2.1 \mathrm{~g}, 11 \mathrm{mmol})$ were added as solid at $23{ }^{\circ} \mathrm{C}$. The same amounts of the acid and $\mathrm{EDCI}-\mathrm{HCl}$ were added after $2 \mathrm{~h}$ and $4 \mathrm{~h}$. One day after the final addition, the reaction mixture was diluted with DMSO $(300 \mathrm{~mL})$, and was loaded onto an F-SPE cartridge $(50 \mathrm{~g})$, and the flask was rinsed with DMSO $(100 \mathrm{~mL})$, and was loaded to the silica gel. The nonfluorous components were eluted with $\mathrm{MeCN}-\mathrm{H}_{2} \mathrm{O}(1: 1,300 \mathrm{~mL}$, and 4:1, $200 \mathrm{~mL})$, and then most of the solvent was drained from the cartridge. The amide coupling product was eluted with $\mathrm{MeCN}(0.4 \mathrm{~L})$. The MeCN solution was concentrated in a rotary evaporator, and the residue was treated with a solution of lithium acetanilide ( $0.33 \mathrm{M}$ in THF, $30 \mathrm{~mL})$. The mixture was refluxed for $1 \mathrm{~h}$. After cooling, AcOH $(0.6$ $\mathrm{mL})$ was added, and the solvent was removed in a rotary evaporator. $\mathrm{MeOH}(30 \mathrm{~mL})$ was added to the residue, and it was heated until the solvent started to boil. The mixture was left at $23^{\circ} \mathrm{C}$ for $1 \mathrm{~d}$, and product $4 \mathrm{~b}\left(\mathrm{R}^{1}=i-\mathrm{Bu}, \mathrm{R}^{2}=4-\mathrm{Cl}\right)$ was collected as a solid by filtration $(3.5 \mathrm{~g}, 69 \%$ yield based on the amount of 2). ${ }^{1} \mathrm{H}$ NMR $\left(270 \mathrm{MHz}, \mathrm{CDCl}_{3}\right) \delta 9.55(\mathrm{~s}, 1 \mathrm{H}), 7.99(\mathrm{~d}, J=8.5 \mathrm{~Hz}, 1 \mathrm{H}), 7.16(\mathrm{dd}$, $J=7.1,1.9 \mathrm{~Hz} 1,), 6.90(\mathrm{~d}, J=1.8 \mathrm{~Hz}, 1 \mathrm{H}), 6.09(\mathrm{~s}, 2 \mathrm{H}), 5.23(\mathrm{~d}, J=13.8 \mathrm{~Hz}, 1 \mathrm{H}), 4.56(\mathrm{~d}, J=13.8$ $\mathrm{Hz}, 1 \mathrm{H}), 4.15-3.85$ (m, 3H), 3.75 (s, 6H), 2.45-2.00 (m, 4H), 1.60-1.45 (m, 1H), 1.35-1.15 (m, 2H), $0.80(\mathrm{~d}, J=6.4 \mathrm{~Hz}, 3 \mathrm{H}), 0.73(\mathrm{~d}, J=6.6 \mathrm{~Hz}, 3 \mathrm{H}) .{ }^{13} \mathrm{C} \mathrm{NMR}\left(67.5 \mathrm{~Hz}, \mathrm{CDCl}_{3}\right) \delta 173.5,165.1,160.6$, $160.1,137.7,136.2,133.3,125.5,124.6,119.4,104.1,90.6,66.3,59.5,55.5,42.0,38.3,27.9(\mathrm{t}, J=$ $22 \mathrm{~Hz}), 25.2,22.3,22.1,20.5$. LC-MS (APCI +) $m / z .893[\mathrm{M}+1]^{+}$.

12. Zhang W, Lu Y. J Comb Chem 2006;8:890-896. [PubMed: 17096578]

13. A general procedure for the synthesis of compounds $\mathbf{5 , 6}$, and 7. To a solution of 4 in $\mathrm{CH}_{2} \mathrm{Cl}_{2}$ was added $t$-butylimino-tris(dimethylamino)phosphorane (10 equiv) and 2-nitrobenzoic acid (2 equiv). The reaction mixture was stirred for $10 \mathrm{~min}$ and then concentrated in a rotary evaporator. The residue was dissolved in DMF $(1 \mathrm{~mL})$ and purified on RapidTrace ${ }^{\circledR}$ SPE workstation with $2 \mathrm{~g}$ cartridges to afford $\mathbf{5}$ in 72-90\% yield. A solution of $\mathbf{5}$ in acetic acid $(1 \mathrm{~mL})$ was added $\mathrm{Zn}$ dust (20 equiv) and 
sonicated at room temperature for $2 \mathrm{~h}$. The $\mathrm{Zn}$ was filtered and the filtrate was diluted with EtOAc and washed with $\mathrm{NaHCO}_{3}$ and brine. The EtOAc solution was dried and concentrated in a rotary evaporator. The residue was dissolved in MeCN and purified by C18 HPLC to afford 6 in 21-73\% yields. A solution of 6 in TFA- $\mathrm{H}_{2} \mathrm{O}-\mathrm{DMS}$ (90:5:5) was stirred for 3 days before being concentrated in a rotary evaporator. The residue was dissolved in DMF $(1 \mathrm{~mL})$ and purified by RapidTrace ${ }^{\circledR} \mathrm{SPE}$ workstation to afford 7 in $63-100 \%$ yields. Analytical date for compound $7 \mathbf{b}\left(\mathrm{R}^{1}=i\right.$ - $\mathrm{Bu}, \mathrm{R}^{2}=4$ $\mathrm{Cl}):{ }^{1} \mathrm{H}$ NMR $\left(275 \mathrm{~Hz}, \mathrm{CDCl}_{3}\right) \delta 0.90(\mathrm{~d}, J=6.5 \mathrm{~Hz}, 3 \mathrm{H}), 1.00(\mathrm{~d}, J=6.5 \mathrm{~Hz}, 3 \mathrm{H}), 1.80-2.05(\mathrm{~m}$, 2H), 2.05-2.25 (m, 1H), 4.10-4.35 (m, 1H), $6.66(\mathrm{~d}, J=6.2 \mathrm{~Hz}, 1 \mathrm{H}), 7.45-7.59(\mathrm{~m}, 2 \mathrm{H}), 7.67(\mathrm{~d}, J$ $=1.9 \mathrm{~Hz}, 1 \mathrm{H}), 7.70-7.85(\mathrm{~m}, 2 \mathrm{H}), 7.91(\mathrm{~d}, J=8.4 \mathrm{~Hz}, 1 \mathrm{H}), 8.31(\mathrm{dd}, J=1.4,8.0 \mathrm{~Hz}, 1 \mathrm{H}) ;{ }^{13} \mathrm{C} \mathrm{NMR}$ $\left(67.5 \mathrm{~Hz}, \mathrm{CDCl}_{3}\right) \delta 22.0,23.1,24.3,38.0,52.4,121.3,127.5,127.8,127.9,128.7,128.9,129.5$, $131.0,134.3,135.2,137.4,146.0,154.1,161.5,167.1$; LCMS (APCI+) $368[\mathrm{M}+1]^{+}$. 


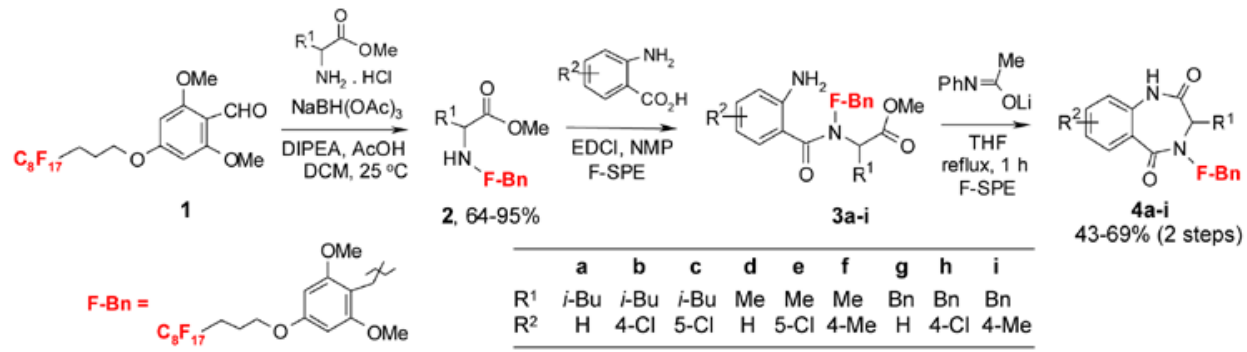

Scheme 1.

Fluorous synthesis of benzodiazepinedione $\mathbf{4}$ 


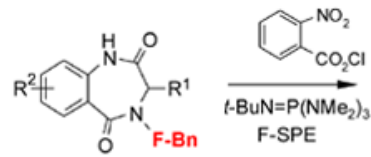

$4 a-i$

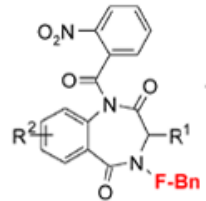

5a-î, $72-90 \%$

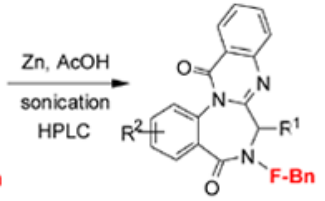

$6 a-i, 21-73 \%$

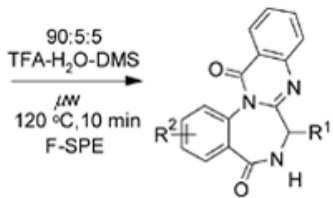

$7 a-i, 63-100 \%$

Scheme 2.

Parallel synthesis of nine benzodiazepine-quinazolinones 7 


\section{Table 1}

Yields for analogs of compounds 5, 6, and 7

\begin{tabular}{lccccccccc}
\hline & $\mathbf{a}$ & $\mathbf{b}$ & $\mathbf{c}$ & $\mathbf{d}$ & $\mathbf{e}$ & $\mathbf{f}$ & $\mathbf{g}$ & $\mathbf{h}$ & $\mathbf{i}$ \\
\hline $\mathrm{R}^{1}$ & $i-\mathrm{Bu}$ & $i$-Bu & $i$-Bu & $\mathrm{Me}$ & $\mathrm{Me}$ & $\mathrm{Me}$ & $\mathrm{Bn}$ & $\mathrm{Bn}$ & $\mathrm{Bn}$ \\
$\mathrm{R}^{2}$ & $\mathrm{H}$ & $4-\mathrm{Cl}$ & $5-\mathrm{Cl}$ & $\mathrm{H}$ & $5-\mathrm{Cl}$ & $4-\mathrm{Me}$ & $\mathrm{H}$ & $4-\mathrm{Cl}$ & $4-\mathrm{Me}$ \\
$\mathbf{5 a - i}$ & $82 \%$ & $80 \%$ & $90 \%$ & $75 \%$ & $94 \%$ & $90 \%$ & $75 \%$ & $72 \%$ & $81 \%$ \\
$\mathbf{6 a - i}$ & $44 \%$ & $50 \%$ & $67 \%$ & $21 \%$ & $51 \%$ & $62 \%$ & $70 \%$ & $65 \%$ & $73 \%$ \\
$\mathbf{7 a - i}$ & $83 \%$ & $86 \%$ & $91 \%$ & $91 \%$ & $63 \%$ & $71 \%$ & $100 \%$ & $89 \%$ & $97 \%$ \\
\hline
\end{tabular}

